\title{
Evaluation and importance of different types of inhaler device in patients with chronic obstructive lung disease
}

\author{
Can ÖZTÜRK ${ }^{1}$ \\ Yağmur ALDAĞ ${ }^{2}$ \\ Nilgün YILMAZ DEMIRCi ${ }^{1}$
}

\footnotetext{
${ }^{1}$ Department of Chest Diseases, Faculty of Medicine, Gazi University, Ankara, Turkey

${ }^{1}$ Gazi Üniversitesi Tıp Fakültesi, Göğüs Hastalıkları Anabilim Dalı, Ankara, Türkiye

${ }^{2}$ Clinic of Chest Diseases, Dr. Burhanettin Nalbantoglu State Hospital Lefkosa, Turkish Republic of Northern Cyprus

${ }^{2}$ Dr. Burhanettin Nalbantoğlu Devlet Hastanesi, Göğüs Hastalıkları Kliniği, Lefkoşa, Kuzey Kıbrıs Türk Cumhuriyeti
}

\section{SUMMARY}

Evaluation and importance of different types of inhaler device in patients with chronic obstructive lung disease

Introduction: Inhaled medications are used in chronic airway disease including chronic obstructive pulmonary disease (COPD) and give the opportunity of low doses, lower side effects, and fast effectiveness. Inhaler devices are frequently used incorrectly by patients. Today, it is generally accepted that poor device use is one of the reasons for poor disease control and low adherence. The aim of the study was to investigate a sample of patients with COPD prescribed with inhaled medication and to evaluate the frequency and pattern of incorrect inhaler use as well as affecting factors.

Materials and Methods: One hundred and eighty consecutive patients who attended the outpatient clinic with the diagnosis of COPD and were prescribed and receiving different types of inhaler drugs at least for one month were included. The patient's ability to use the devices according to steps was scored face to face after they had replied a questionnaire consisting of 26 questions about their inhaler training and disease specifications. The parameters that may affect incorrect use, pattern of incorrect use, characteristics of the patients who experienced incorrect use, and impact of training were evaluated. Chi-Square and Fisher's Exact test were used for statistical analysis.

Results: The rate of correct use including all steps was 26.3\% for metered-dose inhaler (pressurized MDI), 30.4\% for inhalation capsule aerolizer, $40.5 \%$ for diskus, and $46.3 \%$ for turbuhaler. The parameters affecting correct use and number of critical errors causing insufficient drug inhalation were type and duration of initial training due to inhaler devices and also duration and stage of the disease.

Conclusion: COPD patients who were prescribed an inhaler drug should be regularly checked and re-trained during out-patient visits on how to use the inhaler device correctly step by step.

Key words: Chronic obstructive pulmonary diseases, inhaler device, compliance, inhaler technique

\section{Yazışma Adresi (Address for Correspondence)}

Dr. Nilgün YILMAZ DEMIRCi

Gazi Üniversitesi Tıp Fakültesi, Göğüs Hastalıkları

Anabilim Dalı, Beşevler, ANKARA - TURKEY

e-mail: nilgundemirci@gmail.com 


\section{ÖZET}

\section{Kronik obstrüktif akciğer hastalarında farklı tiplerde inhaler cihazların değerlendirilmesi ve önemi}

Giriş: Inhaler ilaçlar, kronik obstrüktif akciğer hastalığı (KOAH) dahil olmak üzere kronik hava yolu hastalıklarında kullanılır ve düşük doz, düşük yan etki ve hızı etkinlik imkanı verir. Inhhaler cihazlar sıklıkla hastalar tarafından hatalı kullanılır. Günümüzde, kötü cihaz kullanımının yetersiz hastalık kontrolünün ve kötü uyum nedenlerinden biri olduğu genel olarak kabul edilmektedir. Çalışmanın amacı, inhaler tedavi verilen KOAH'lı hasta örneklemini araştırmak ve yanlış inhaler kullanımının sıklığını ve şeklini ve etkileyen faktörleri değerlendirmektir.

Materyal ve Metod: $K O A H$ tanısı ile polikliniğe başvuran ve en az bir aydır farklı türlerde inhaler ilaç kullanan ardışık180 hasta dahil edildi. Hastaların inhaler kullanabilme becerileri yüz yüze görüşülerek skorlandı ve sonra inhaler eğitimi ve hastalık özellikleri ile ilgili 26 sorudan oluşan bir anket formunu yanıtlamaları istendi. Yanlış kullanımı etkileyen parametreler, yanlış kullanım paterni, yanlış kullanan hastaların özellikleri ve eğitimin etkisini değerlendiren parametreler analiz edildi. Istatistiksel analiz için Ki-kare ve Fisher's Exact test kullanıldı.

Bulgular: Tüm adımları içeren doğru kullanım oranı, ölçülü doz inhaler (basınçlı MDI) için \%26.3, inhaler kapsül için \%30.4, diskus için $\% 40.5$ ve turbuhaler için \%46.3 idi. Doğru ilaç kullanımını ve yetersiz ilaç inhalasyonuna neden olan kritik hataların sayısını etkileyen parametreler, inhaler cihazların başlangıç eğitiminin tipi ve süresi ile hastalı̆̆ın süresi ve evresi idi.

Sonuç: Inhaler ilaç reçete edilen KOAH hastaları, ziyaretleri sırasında düzenli olarak inhaler cihazını adım adım nasıl doğru kullanacağı kontrol edilmeli ve yeniden eğitilmelidir.

Anahtar kelimeler: Kronik obstrüktif akciğer hastalı̆̆ı, inhaler cihaz, uyum, inhaler tekniği

\section{INTRODUCTION}

Chronic obstructive pulmonary disease (COPD) continues increasingly to be the cause of morbidity and mortality all over the world. It has been reported that more than 210 million people in the world are involved and that COPD ranks fourth among the causes of death (1). Reducing symptoms, decreasing frequency and severity of exacerbations, enhancing exercise tolerance, and improving health status are among the goals of treatment to prolong survival and to improve quality of life in COPD patients (2). Many drugs including long-acting beta2 agonists (LABAs), combination of LABAs and inhaled corticosteroids, long-acting antimuscarinic agents, phosphodiesterase-4 inhibitors, and macrolides are used in pharmacological treatment of COPD (2).

Drug delivery via inhalation is gradually increased in the treatment of pulmonary infections due to its local and fast-acting effects as well as to less systemic adverse events. Inhalation is the preferred route of administration for many drugs used in the treatment of COPD and inhalation devices are the main tools for effective delivery of inhaled agents (3). Advantages of delivering the drug directly via inhalation to where it would be effective are the facts that the amount of drug required can be decreased and systemic adverse events can be minimized within the effective dose range (3). Moreover, it has been reported that several factors may influence the approaches of patients with COPD to inhalation therapy and their preference of different devices (4-6). Efficacy of inhalation therapy depends on pharmacological and physical properties of drug formulation, administration of drug by an accurate technique, and patient compliance. Although patient compliance has an important role in the treatment of every disease, it becomes particularly essential for patients receiving inhalation therapy. Patient compliance is of great importance for the success of medical therapy in COPD patients and is influenced by many factors (7). Recently, the concept of personalized medicine in COPD has become into question (8). Treatment compliance is substantially influenced by a patient's attitude toward chronic medications, the preferred inhaler, and experiences. It is assumed that patients, who are using an inhaler that they prefer, would be more satisfied with treatment and would better comply with the drug, which would provide better clinical outcomes and decrease health expenditure $(5,9)$. The most important issues considered in chose of inhalers have been reported to be the ease of use of device, inhalation technique, patient's preference, and cost-effectiveness $(3,10)$. The present study aimed to assess frequency of misusage of inhalers and the affecting factors in COPD patients.

\section{MATERIALS and METHODS}

Patients with COPD who presented to the Chest Diseases Policlinic of Gazi University Faculty of Medicine and were receiving inhaled drugs for at least one month were included. Approval of the local 
ethics committee and informed consents of the patients were obtained for the study.

Demographic information, COPD-related clinical information, and inhalation device-related information were obtained from the patients by applying a questionnaire and recorded. In the second step, the patients were asked to use their inhalation devices in the way they always used. While the patients were using their inhalation devices, each step of their use was observed by a physician and then the questionnaire was filled. For this purpose, a questionnaire, which was developed for each of HandiHaler, inhalation capsule aerolizer, Turbuhaler, Diskus, and metered-dose inhaler (MDI) devices and included questions about the steps of appropriate use, was used. The misuses were recorded. Critical mistakes for each device were defined as the mistakes occurred in the steps such as opening the device, initiation of dosing, and/or inhalation, which resulted in not inhaling the drug or serious dose loss. After completing the questionnaire and evaluating the device use, the patients who misused their devices were trained and provided to use their devices appropriately.

\section{Statistical Analysis}

Data were analyzed using the Statistical Package for the Social Sciences (SPSS Inc., Chicago, IL, USA) version15.0 for Windows. Descriptive statistics were expressed as number and percentage for categorical variables and as mean \pm standard deviation and median (minimum-maximum) for $<$ numerical variables. For categorical independent variables, chisquare test was used both for two group and multiple group comparisons when chi-square condition was met; whereas, Fisher's Exact test was used for two group comparisons and Monte Carlo simulation was used for multiple group comparisons when chisquare condition was not met. A p value $<0.05$ was considered statistically significant.

\section{RESULTS}

The mean age of 180 patients with COPD was 64.11 \pm 10.77 years and 133 of them were male. Demographic and clinical characteristics of the patients are presented in Table 1.

Three-hundred and six questionnaire forms were completed for 5 devices used by the patients. Inhalation devices used by the patients are presented in Table 2. Some patients used more than one device. It was determined that inhalation device was changed in $41(22.9 \%)$ patients, of whom 31 were changed by
Table 1. Demographic and clinical characteristics of the patients with chronic obstructive pulmonary disease

\begin{tabular}{ll}
\hline Characteristics & \\
\hline Gender & $47(26.1)$ \\
$\quad$ Female & $133(73.9)$ \\
$\quad$ Male & $64.11 \pm 10.77$ \\
Age, year & \\
Age, year & $95(52.8)$ \\
$\quad \leq 65$ years & $85(47.2)$ \\
$\quad>65$ years & \\
Education level & $79(43.9)$ \\
$\quad<$ High school & $101(56.1)$ \\
$\quad \geq$ High school & $5.24 \pm 4.52$ \\
Disease duration, year & \\
Disease group* & \\
A & $41(22.8)$ \\
B & $45(25.0)$ \\
C & $40(22.2)$ \\
D & $54(30.0)$ \\
\hline $\begin{array}{l}\text { Data are presented as mean } \pm \text { standard deviation or number }(\%), \\
\text { * According to the GOLD 2014 guideline }(11) .\end{array}$ \\
\hline
\end{tabular}

the physician and 10 were changed on the patient's demand over the course of treatment period (Table 2).

One hundred and thirty-one (72.8\%) patients stated that they received the initial education about the application of inhalation device from the physician who prescribed the drug, whereas 37 (20.6\%) patients stated that they received the initial education from the pharmacist. Of these patients, $60 \%$ were in the opinion that the education was adequate (Table 3).

Of the patients, 155 (86.1\%) reported that the physician did not ask them to test different inhalation devices before prescribing the inhaler. The patients rated the ease of using the devices as very easy, easy, difficult, very difficult, or no idea. After excluding those stated as no idea from the analyses, those stated as easy + very easy were compared with those stated as difficult + very difficult. No difference was found between the devices in terms of ease of use (Table 4).

For the question "on which subject do you have difficulty or hesitation while using inhalation device", 115 patients $(63.9 \%)$ answered as they did not experience any difficulty. While 15 patients $(8.3 \%)$ 
Table 2. Information on inhalation devices of the patients with chronic obstructive pulmonary disease

\begin{tabular}{|c|c|}
\hline & n $(\%)$ \\
\hline \multicolumn{2}{|l|}{ Currently used inhalation device* } \\
\hline HandiHaler & $99(55.0)$ \\
\hline Metered-dose inhaler & $77(42.8)$ \\
\hline Aerolizer inhalation capsules & $46(25.6)$ \\
\hline Turbuhaler & $42(23.3)$ \\
\hline Diskus & $42(23.3)$ \\
\hline Change of the device & $41(22.8)$ \\
\hline \multicolumn{2}{|l|}{ Reason for the physician to change the device } \\
\hline Drug's being insufficient & $10(32.3)$ \\
\hline Patient's non-compliance with the device & $10(32.3)$ \\
\hline Does not remember & $9(29.0)$ \\
\hline Drug's being insufficient + Patient's non-compliance with the device & $2(6.5)$ \\
\hline \multicolumn{2}{|l|}{ Reason for the patient to ask for changing the device } \\
\hline Difficulty in inhaling & $4(40.0)$ \\
\hline Thinking that it is useless & $2(20.0)$ \\
\hline Non-compliance with the device & $2(20.0)$ \\
\hline Thinking that it is useless+ Non-compliance with the device & $1(10.0)$ \\
\hline Noncompliance with the device + Difficulty in inhaling & $1(10.0)$ \\
\hline
\end{tabular}

stated that they had difficulty during preparation phase, 14 patients $(7.8 \%)$ stated that they were not sure that they inhaled accurately. Eleven patients $(6.1 \%)$ indicated that they sometimes were not sure or did not remember whether they received the drug. Ten patients $(5.6 \%)$ stated that they failed to inhale adequately.

It was determined that 17 patients $(9.5 \%)$ discontinued their inhaled medication at any time over the course of treatment period without notifying their physicians. The reasons for discontinuing inhaled medication were as follows: considering it as not beneficial $(n=11)$, not being in need of it $(n=2)$, non-compliance with the device $(n=2)$, considering it as not beneficial + noncompliance with the device $(n=2)$, and having difficulty during preparation phase $(n=1)$. One patient was reluctant to answer.

Patients having $\leq 3$ and $>3$ mistakes during the use of device were compared and no difference was determined between the groups in terms of gender and age. Education status, disease stage, trainer that give education about the use of device and training duration and testing different inhalation devices prior to prescription were found to be associated with the number of mistakes (Table 5).
When the patients having $\leq 2$ and $>2$ critical mistakeswere compared, no difference was found in terms of gender, age, and education status. Disease stage, trainer for the usage of device, and duration of training were found to be associated with the number of critical mistakes. No difference was determined between the critical mistake groups in terms of testing various inhalation devices before prescription (Table 6).

Distribution of the patients having $\leq 3$ and $>3$ mistakes according to the inhalation devices is presented in Table 7 . The rate of making $>3$ mistakes was not different between the types of devices.

Critical mistakes of the patients in using inhalation devices were evaluated. The rate of having $>2$ critical mistakes was not different between the types of devices (Table 8).

The rate of performing all application steps accurately while applying inhalation devices is presented in Table 9. The rate of performing all application steps accurately was not different between the types of devices. 


\section{Table 3. Information on the education regarding the application of inhalation device}

Person giving the initial training about the application of inhalation device

The physician who prescribed the drug

Pharmacist

Nobody; only the brochure was given

Another patient

Nobody; only the prescribing information was read

Nurse of the institution where the drug was prescribed

Who should give the initial education on inhalation

The physician who prescribed the drug

The physician who prescribed the drug + Pharmacist

Pharmacist

Nurse of the institution where the drug was prescribed

The physician who prescribed the drug + Nurse of the institution

No need for description, brochure was enough

Duration of hands-on training with inhalation device

$<5$ minutes

5-15 minutes

Does not remember the duration

Never told

Is the training for the use of inhalation device adequate?

No

Yes

No idea

Did not receive the initial information or training

Why was the training on the use of inhalation device inadequate?

The trainer did not spare enough time

The trainer did not spare enough time + could not explain clearly

The trainer could not explain clearly

I could not understand the words used (medical terms)

The trainer did not spare enough time + I could not focus/ listen attentively

Application for additional training on the use of inhalation device

I re-consulted the physician that prescribed the drug

I consulted the pharmacist

I consulted another patient

I consulted the pharmacist + I re-consulted the physician that prescribed the drug

I consulted the pharmacist + I consulted another patient

I consulted no one, read from the brochure 
Table 4. Ease of use of the devices

\begin{tabular}{|lccc} 
& Easy + Very easy & Difficult + Very difficult \\
Inhalation device & $\mathbf{n}(\mathbf{\%})$ & ( ) & p \\
\hline HandiHaler & $67(75.3)$ & $22(24.7)$ \\
Aerolizer inhalation capsules & $33(84.6)$ & $6(15.4)$ & 0.614 \\
Turbuhaler & $29(78.4)$ & $8(21.6)$ & $12(30.0)$ \\
Diskus & $28(70.0)$ & $18(26.1)$ \\
Metered-dose inhaler & $51(73.9)$ & & \\
\hline
\end{tabular}

\section{Table 5. Characteristics of the groups according to the number of mistakes in using the device}

\begin{tabular}{|c|c|c|c|}
\hline & $\leq 3$ mistakes & $>3$ mistakes & $\mathbf{p}$ \\
\hline \multicolumn{4}{|l|}{ Gender } \\
\hline Female & 38 (80.9) & $9(19.1)$ & \multirow{2}{*}{0.241} \\
\hline Male & $96(72.2)$ & $37(27.8)$ & \\
\hline \multicolumn{4}{|l|}{ Age group } \\
\hline$\leq 65$ years & $73(76.8)$ & $22(23.2)$ & \multirow{2}{*}{0.436} \\
\hline$>65$ years & $61(71.8)$ & $24(28.2)$ & \\
\hline Age, year & $63.39 \pm 11.06$ & $66.2 \pm 9.68$ & 0.197 \\
\hline \multicolumn{4}{|l|}{ Education status } \\
\hline$<$ High school & $49(62.0)$ & $30(38.0)$ & \multirow{2}{*}{0.001} \\
\hline$\geq$ High school & $85(84.2)$ & $16(15.8)$ & \\
\hline \multicolumn{4}{|l|}{ Disease stage } \\
\hline A & $36(87.8)$ & $5(12.2)$ & \multirow{4}{*}{0.001} \\
\hline B & $38(84.4)$ & 7 (15.6) & \\
\hline $\mathrm{C}$ & $30(75.0)$ & $10(25.0)$ & \\
\hline $\mathrm{D}$ & $30(55.6)$ & $24(44.4)$ & \\
\hline \multicolumn{4}{|c|}{ The person who gave the initial education about applying the device } \\
\hline The physician who prescribed the drug & $111(86.0)$ & $18(14.0)$ & \multirow{2}{*}{$<0.001$} \\
\hline Pharmacist & $21(56.8)$ & $16(43.2)$ & \\
\hline \multicolumn{4}{|c|}{ Testing various inhalation devices before prescribing the drug } \\
\hline No & $110(71.0)$ & $45(29.0)$ & \multirow{2}{*}{0.009} \\
\hline Yes & $23(95.8)$ & $1(4.2)$ & \\
\hline \multicolumn{4}{|c|}{ Duration of explaining the application of inhalation device } \\
\hline$<5$ minutes & $86(75.4)$ & $28(24.6)$ & \multirow[t]{4}{*}{$<0.001$} \\
\hline 5-15 minutes & $45(91.8)$ & $4(8.2)$ & \\
\hline Does not remember the duration & $3(42.9)$ & $4(57.1)$ & \\
\hline Never explained & $0(0.0)$ & $10(100.0)$ & \\
\hline
\end{tabular}




\section{Table 6. Characteristics of the groups according to the number of critical mistakes}

\begin{tabular}{|c|c|c|c|}
\hline & $\leq 2$ critical mistakes & $>2$ critical mistakes & $\mathbf{p}$ \\
\hline \multicolumn{4}{|l|}{ Gender } \\
\hline Female & $44(95.7)$ & $2(4.3)$ & \multirow{2}{*}{1.000} \\
\hline Male & $125(94.0)$ & $8(6.0)$ & \\
\hline \multicolumn{4}{|l|}{ Age group, year } \\
\hline$\leq 65$ years & $90(95.7)$ & $4(4.3)$ & \multirow{2}{*}{0.521} \\
\hline$>65$ years & $79(92.9)$ & $6(7.1)$ & \\
\hline Age, year & $63.96 \pm 10.79$ & $66.9 \pm 10.99$ & 0.456 \\
\hline \multicolumn{4}{|l|}{ Education status } \\
\hline$<$ High school & $71(91.0)$ & $7(9.0)$ & \multirow{2}{*}{0.106} \\
\hline$\geq$ High school & $98(97.0)$ & $3(3.0)$ & \\
\hline \multicolumn{4}{|l|}{ Disease stage } \\
\hline A & $40(97.6)$ & $1(2.4)$ & \multirow{4}{*}{0.044} \\
\hline B & $43(97.7)$ & $1(2.3)$ & \\
\hline $\mathrm{C}$ & $39(97.5)$ & $1(2.5)$ & \\
\hline $\mathrm{D}$ & $47(87.0)$ & $7(13.0)$ & \\
\hline \multicolumn{4}{|c|}{$\begin{array}{l}\text { Person who gave the initial education about the } \\
\text { application of device }\end{array}$} \\
\hline The physician that prescribed the drug & $127(99.2)$ & $1(0.8)$ & \multirow{2}{*}{0.009} \\
\hline Pharmacist & $33(89.2)$ & $4(10.8)$ & \\
\hline \multicolumn{4}{|c|}{ Testing various inhalation devices before prescribing the drug } \\
\hline No & $145(94.2)$ & $9(5.8)$ & \multirow{2}{*}{1.000} \\
\hline Yes & $23(95.8)$ & $1(4.2)$ & \\
\hline \multicolumn{4}{|c|}{ Duration of explaining the application of inhalation device } \\
\hline$<5$ minutes & $109(96.5)$ & $4(3.5)$ & \multirow{4}{*}{0.009} \\
\hline 5-15 minutes & $47(95.9)$ & $2(4.1)$ & \\
\hline Does not remember the duration & $6(85.7)$ & $1(14.3)$ & \\
\hline Never explained & $7(70.0)$ & $3(30.0)$ & \\
\hline
\end{tabular}

\section{Table 7. Distribution of the patients having $\leq 3$ and $>3$} mistakes according to the inhalation devices

\begin{tabular}{|lccc|}
\hline Inhalation device & $\leq \mathbf{3}$ mistakes & $\begin{array}{c}\mathbf{>} \text { m } \\
\text { mistakes }\end{array}$ & $\mathbf{p}$ \\
\hline $\begin{array}{l}\text { HandiHaler } \\
\text { Aerolizer inhalation } \\
\text { capsule }\end{array}$ & $34(78.8)$ & $21(21.2)$ & \\
$\begin{array}{l}\text { Turbuhaler } \\
\text { Diskus }\end{array}$ & $35(83.3)$ & $7(16.7)$ & 0.145 \\
$\begin{array}{l}\text { Metered-dose } \\
\text { inhaler }\end{array}$ & $52(67.5)$ & $25(32.5)$ & \\
\hline & $35(85.4)$ & $6(14.6)$ & \\
\hline
\end{tabular}

\section{DISCUSSION}

Adequate amount of drug needs to be delivered to the bronchial mucosa for the inhalation devices used in the treatment of COPD to be effective. This is only possible with appropriate application technique. Considering also the variety of marketed inhalation devices, explanation of appropriate application of these devices brings additional labor and time load to the physicians. As the consequence, patients do not receive adequate training and sometimes even the application of device is not described. Moreover, cognitive and physical inability of the patients, not preferring the device appropriate for the patient, and educational and sociocultural differences may also cause problems such as noncompliance with inhalation therapy as well as inability of using or misusing the device $(12,13)$. Vander Schaaf et al. determined that $40 \%$ of COPD patients have not 
Table 8. Distribution of devices according to the number of critical mistakes during the use of inhalation device

\begin{tabular}{|c|c|c|c|}
\hline Inhalation device & $\begin{array}{l}\leq 2 \text { critical } \\
\text { mistakes }\end{array}$ & $\begin{array}{c}>2 \text { critical } \\
\text { mistakes }\end{array}$ & p \\
\hline HandiHaler & $97(0.99)$ & $1(1.0)$ & \\
\hline $\begin{array}{l}\text { Aerolizer } \\
\text { inhalation capsule }\end{array}$ & $42(91.3)$ & $4(8.7)$ & \\
\hline Turbuhaler & $41(97.6)$ & $1(2.4)$ & 0.177 \\
\hline Diskus & $73(94.8)$ & $4(5.2)$ & \\
\hline $\begin{array}{l}\text { Metered-dose } \\
\text { inhaler }\end{array}$ & $38(92.7)$ & $3(7.3)$ & \\
\hline
\end{tabular}

Table 9. Patients performing all application steps accurately or having at least one mistake according to the device

\begin{tabular}{|lccc|}
\hline Inhalation device & $\begin{array}{c}\text { All steps } \\
\text { are correct }\end{array}$ & $\begin{array}{c}\text { At least one } \\
\text { incop is } \\
\text { incorrect }\end{array}$ & p \\
\hline $\begin{array}{l}\text { HandiHaler } \\
\begin{array}{l}\text { Aerolizer } \\
\text { inhalation capsule }\end{array}\end{array}$ & $43(43.9)$ & $55(56.1)$ & \\
$\begin{array}{l}\text { Turbuhaler } \\
\text { Diskus }\end{array}$ & $19(46.3)$ & $22(53.7)$ & 0.082 \\
$\begin{array}{l}\text { Metered-dose } \\
\text { inhaler }\end{array}$ & $17(40.5)$ & $25(59.5)$ & \\
\hline & $20(26.3)$ & $56(73.7)$ & \\
\hline
\end{tabular}

been using the inhalation device as was prescribed (14). Restrepo et al. conducted a review and reported that $40-60 \%$ of the patients were compliant with the prescribed regimen and that only one out of 10 patients has followed the necessary steps properly in using the inhalers (15). In their systematic review, Lavorini et al. Reported the rate of patients that have been using the inhaler correctly between $4 \%$ and $94 \%$ depending on the type of inhaler and assessment method (16). Not using the inhalation device properly makes it difficult to control the disease and both abuses the trust in treatment and pose additional burden to the health expenditures of the country due to the use of higher amount of drug, higher adverse events, more frequent attacks and more hospital admissions (17).

Studies that evaluated various parameters effective on proper or misusage of inhalation devices reported different results. Effect of age and gender on the application skills for inhalation device has been investigated in the studies. Rootmensen et al. determined that the rate of misusage is higher in $\geq 60$ year-age group with no difference between the genders (18). Mirici et al. reported that females and younger people are more successful in applying the device (19). However, Goodman et al. reported that females make more mistakes in the application of device and that there is no difference between young and old patients in terms of technical aspec (20). Şen et al. determined that young patients use the inhalation devices more properly as compared to the old patients (21). Van Beerendonk et al. reported that there is no relation between gender and appropriate use of inhalers (22). In the present study, the rates of mistakes and critical mistakes while using inhalers were higher in males and in advanced ages without achieving statistical significance.

As well as the studies reporting that education level is an effective factor on the skills for applying the device, there are studies reporting that it is not (18, $19,21,23)$. In the present study, the rate of making $>$ 3 mistakes in using the devices was found to be significantly higher in those with low education level (38\% vs. $15.8 \%, p=0.001$ ). The difference between education groups in terms of making critical mistakes has not achieved statistical significance. Patient education is one of the major issues for appropriate use of inhaled drugs. It was demonstrated that patients that have not received education about the application of inhalation device make significantly more mistakes $(18,21)$. It was demonstrated that training the patients about the application of inhaled drugs enhances technical skills $(23,24)$. Therefore, it is apparent that health care worker should sufficiently know how to apply inhaled drugs. Nevertheless, it is reported that knowledge and skills of health care staffs particularly on the use of newly introduced devices are not sufficient (25). In a study that evaluated knowledge of health care workers on the use of inhaled drugs, the rate of appropriate usage was found to be $81.6 \%$ among respiration therapists, $77.7 \%$ among primary care physicians, $57.7 \%$ among pharmacists, $54.4 \%$ among nurses and $53.8 \%$ among trainees considering three different devices together. When all health care workers were considered together according to the device, the rate of appropriate application was $80.9 \%$ for $\mathrm{MDI}, 64.2 \%$ for diskus and $49.9 \%$ for turbuhaler (26). In Turkey, deficiencies have been demonstrated in the knowledge of specialists, trainee physicians, nurses and pharmacists in terms of application of inhaled drugs (27). It is reported that both users and prescribers need continuous education on the use of these 
devices to enhance the efficacy of treatment (28). In the present study, $72.8 \%$ of the patients received the initial information about the application of inhalation device from the physician prescribed the drug and $20.6 \%$ received from the pharmacist. While $60 \%$ of the patients found the education adequate, $19.4 \%$ stated that it is inadequate. Of the patients that found the education inadequate, $69.4 \%$ stated that the trainer did not spare enough time, whereas $13.9 \%$ complained about both that enough time has not been spared and explanation was not clear. Consequently, $35.9 \%$ of the patients re-consulted the physician that made prescription, $20.5 \%$ re-consulted the pharmacist and $10.3 \%$ re-consulted both the physician and the pharmacist and asked for additional education. In the present study, the rates of the patients that made $>3$ mistakes and $>2$ critical mistakes during the application of device were statistically significantly higher among the patients that received education form pharmacists as compared to the patients that received education from the physicians that made the prescription. Every physician that prescribes inhaled drugs, primarily the chest diseases specialists, should know how to apply inhalation devices and should give hands-on training to the patients. Almost all of these patients have been treated as in patients in a period of their lives. Therefore, it is necessary particularly for clinic nurses, who give drugs to the patients, to know how to apply the drug and to monitor the patients how they apply. It is apparent that the pharmacists as well should be informed about this subject. Van der Palen et al. conducted a randomized controlled trial in 152 COPD patients and applied three different models of education and determined that explaining the patients how to apply the drug by medical staff alone is more efficient and that education via video as well gives good results (29). In the study conducted by Lee-Wong and Mayo, the rate of appropriate application of $\mathrm{MDI}$ devices was 5\% among new medical interns, whereas it increased to $13 \%$ after lecture and demonstration and to $73 \%$ after intensive one-on-one training session with an attending physician (30). Effect of education on appropriate application of devices is not a matter of debate. Abadoğlu et al. observed that appropriate application of inhalers reached to $100 \%$ after education, which was $53 \%$ before education (31). The present study as well determined significantly lower rates of mistakes in applying inhalation devices among those educated versus non-educated.
Today, MDIs are among the most commonly prescribed inhalation devices. As MDI devices require more patient coordination and cognitive ability, the rate of misusage is higher (32). The rate of making at least one mistake in applying MDI was found to be $71-89 \%(22,33,34)$. The most common mistakes include failing to inhale during puff and not exhaling before inhaling $(22,35)$. The rate of misusage was reported to be $7-43 \%$ in the studies conducted with dry powder inhalation devices $(18,34)$. With regard to the mistakes made during the application of devices in the present study, although the rate of making $>3$ mistakes was the highest with diskus $(32.5 \%)$ and the lowest with MDI (14.6\%), no statistically significant difference was found between five devices in terms of rate of misusage $(p=0.145)$. Whilst the rate of making more than two critical mistakes was the highest with aerolizer inhalation capsules $(8.7 \%)$, again no statistically significant difference was determined between five devices in terms of critical mistakes $(p=0.177)$. Although the rate of performing all steps of application without mistake was the highest with turbuhaler $(46.3 \%)$, no statistically significant difference was found between the devices $(p=0.082)$. Mirici et al. determined no difference between the types of device in the patients using $\mathrm{MDI}$, turbuhaler, spinhaler and diskus in terms of the rate of appropriate usage (19).

Mistakes in using inhalation devices are important handicaps for the patients to benefit from their treatment. In the present study, it was determined that $9.5 \%$ of the patients discontinued their treatment in a period over the course of their diseases and among these patients, the rate of those thinking that drugs are not beneficial for them was found to be $57.9 \%$. In the study conducted by VanderSchaafet al. patients reported the reason for not using the inhalation device to be the feeling that inhalers did not help breathing (20\%) (14). Such substantial loss of compliance with and involvement in treatment cause considerable problems in terms of long-tern complications and disease management.

George et al. determined that COPD patients with lack of compliance with treatment and involvement in treatment do not understand their disease enough, do not take it seriously, do not know how to manage their treatment and disease, do not trust in their physician enough, and believe in complementary medicine more (36). In the same study, ease of applicability of device and adequate information 
given by the doctor were determined to be the factors that enhance compliance with and involvement in treatment in the patients. In the present study, evaluating patients' opinion concerning the difficulty/ ease of application of the devices, it was determined that aerolizer inhalation capsules are the devices used most easily $(84.6 \%)$, whereas diskus is the device most difficult to use (30\%). Nevertheless, no statistical difference was determined between the inhalation devices evaluated in the present study in terms of ease of use reported by the patients $(p=$ 0.614). Based on our findings, the device used most easily was reported to be inhalation capsule aerolizer by the patients; however, the highest rate of making critical mistake was reported in using the same device. Contrarily, diskus was reported to be the device, of which the usage is most difficult; however, this device was determined to be the device that ranked second in making the least critical mistake while using. Accordingly, it can be concluded that the patients are inattentive and do not follow the instructions while using the devices they deem easy to use and contrarily they use the device that they deem difficult to use more attentively.

The rate of making $>3$ mistakes and $>2$ critical mistakes in using the device did not show statistically significant difference among disease stages (groups) and it was observed that higher mistakes have been made in group D. This might be due to impaired muscle strength and coordination as disease stage is advanced, unfavorable effects of other concomitant diseases on motor skills and cognitive functions, and decrease in attention necessary to be paid while using the device during long-term use.

The present study demonstrated that asking the patients to test different devices before the prescription of inhalation devices generated favorable outcomes. It was determined that patients that tested different devices before prescription made significantly lower mistakes while using the devices. The conclusion is that, selecting devices appropriate for own skills of each patient would enhance treatment compliance and therapy success.

In conclusion, evaluating the results of the study all together, we are of the opinion that patients in whom inhalation device would be prescribed for COPD should be assessed in detail; education status and disease stage would be effective on the application of device and accordingly on the efficacy of treatment; the most appropriate device must be chosen by testing different devices before prescription; initial education on the inhalation devices should be given by the relevant physician in detail and sparing adequate time for each patient; information that are given to the patients in the pharmacies needs to be improved via in-service training; and regular monitoring of the patients over the course of their treatment and re-educating about the use of inhalation device when necessary would be appropriate approach.

\section{REFERENCES}

1. Diaz-Guzman E, Mannino DM. Epidemiology and prevalence of chronic obstructive pulmonary disease. Clin Chest Med 2014;35:7-16.

2. Rosenberg $S R$, Kalhan R. An integrated approach to the medical treatment of chronic obstructive pulmonary disease. Med Clin North Am 2012;96:811-26.

3. Salvi S, Gogtay J, Aggarwal B. Use of breath-actuated inhalers in patients with asthma and COPD - an advance in inhalational therapy:a systematic review. Expert Rev Respir Med 2014;8:89-99.

4. Osman LM, Hyland ME. Patient needs and medication styles in COPD. Eur Respir Rev 2005; 14:89-92.

5. Hodder R. Design and interpretation of device preference trials: marketing tools or scientific instruments? Respiratory Drug Delivery 2006;1:19-36.

6. Anderson P. Patient preferences for and satisfaction with inhaler devices. Eur Respir Rev 2005;14:109-16.

7. Sanduzzi A, Balbo P, Candoli P, Catapano GA, Contini P, Mattei $A$, et al. COPD: adherence to therapy. Multidiscip Respir Med 2014;9:60-8.

8. Agusti A. The path to personalised medicine in COPD. Thorax 2014;69:857-64.

9. Jones R, Hyland ME, Hanney K, Erwin J. A qualitative study of compliance with medication and lifestyle modification in Chronic Obstructive Pulmonary Disease (COPD). Prim Care Respir J 2004; 13:149-54.

10. Laube BL, Janssens $H M$, de Jongh FH, Devadason SG, Dhand R, Diot P, et al; European Respiratory Society; International Society for Aerosols in Medicine. What the pulmonary specialist should know about the new inhalation therapies. Eur Respir J 2011;37:1308-31.

11. Global Initiative for Chronic Obstructive Lung Disease (GOLD). Global strategy for the diagnosis, management, and prevention of chronic obstructive pulmonary disease: updated 2014. http://www.goldcopd.com

12. Erk M. Inhalasyon teknikleri. Toraks Dergisi (Ek) 2002;3:7-13. 
13. Chapman KR, Voshaar TH, Virchow JC. Inhaler choice in primary practice. Eur Respir Rev 2005; 14:117-22.

14. VanderSchaaf K, Olson KL, Billups S, Hartsfield CL, Rice M. Self-reported inhaler use in patients with chronic obstructive pulmonary disease. Respir Med 2010;104:99-106.

15. Restrepo RD, Alvarez MT, Wittnebel LD, Sorenson $H$, Wettstein $R$, Vines $D L$, et al. Medication adherence issues in patients treated for COPD. Int J Chron Obstruct Pulmon Dis 2008;3:371-84.

16. Lavorini F, Magnan A, Dubus JC, Voshaar T, Corbetta L, Broeders $M$, et al. Effect of incorrect use of dry powder inhalers on management of patients with asthma and COPD. Respir Med 2008; 102:593-604.

17. Rau JL. Practical problems with aerosol therapy in COPD. Respir Care 2006;51:158-72.

18. Rootmensen $G N$, van Keimpema AR, Jansen HM, de Haan RJ. Predictors of incorrect inhalation technique in patients with asthma or COPD: a study using a validated videotaped scoring method. I Aerosol Med Pulm Drug Deliv 2010;23:323-8.

19. Mirici A, Meral $M$, Akgün $M$, Sağlam, Inandı T. Factors effecting patients compliance to inhalation techniques. Solunum Hastalıkları 2001;12:13-21.

20. Goodman DE, Israel $E$, Rosenberg $M$, Johnston $R$, Weiss $S T$, Drazen JM. The influence of age, diagnosis, and gender on proper use of metered-dose inhalers. Am J Respir Crit Care Med 1994;150:1256-61.

21. Şen E, Gönüllü U, Ekici Z, Kurşun N. Assessment of inhaler technique and treatment compliance of hospitalized patients and outpatients in a university hospital. Ankara Üniversitesi Tıp Fakültesi Mecmuası 2006;59:1-6.

22. vanBeerendonk I, Mesters I, Mudde AN, Tan TD. Assessment of the inhalation technique in outpatients with asthma or chronic obstructive pulmonary disease using a metered-dose inhaler or dry powder device. I Asthma 1998;35:273-9.

23. Aydemir Y. Misuse of inhalation devices-effective parameters and the role of education. Solunum 2013;15:32-8.

24. Windsor RA, Bailey WC, Richards JM Jr, Manzella B, Soong SJ, Brooks M. Evaluation of the efficacy and cost effectiveness of health education methods to increase medication adherence among adults with asthma. Am J Public Health 1990;80:1519-21.
25. Hanania NA, Wittman R, Kesten S, Chapman KR. Medical personel's knowledge of and ability to use inhaling devices. Metered-dose inhalers, spacing chambers, and breathactuated dry powder inhalers. Chest 1994;105:111-6.

26. Chopra N, Oprescu N, Fask A, Oppenheimer J. Does introduction of new "easy to use" inhalational devices improve medical personnel's knowledge of their proper use? Ann Allergy Asthma Immunol 2002;88:395-400.

27. Ünlü $M$, Şahin Ü, Öztürk $M$, Akkaya A. Assessment of inhaler techniques among the medical personnel and pharmacists. Solunum Hastalıkları 2001;12:8-12.

28. Molimard M, Raherison C, Lignot S, Depont F, Abouelfath, Moore N. Assessment of handling of inhaler devices in real life: an observational study in 3811 patients in primary care. J Aerosol Med 2003;16:249-54.

29. van der Palen J, Klein JJ, Kerkhoff AH, van Herwaarden CL, Seydel ER. Evaluation of the long-term effectiveness of three instruction modes for inhaling medicines. Patient Educ Couns 1997;32(1 Suppl):S87-95.

30. Lee-Wong $M$, Mayo PH. Results of a programme to improve house staff use of metered dose inhalers and spacers. Postgrad Med J 2003;79:221-5.

31. Abadoğ/u Ö, Yalazkısa S, Ülger G, Paşaoğ/u G, Mısırlıgil Z. The role of education by a well-trained nurse on correct utilization of inhalation devices. T KlinAllerji J AllergyAsthma 2003;5:11-5.

32. Lenney J, Innes JA, Crompton GK. Inappropriate inhaler use: assessment of use and patient preference of seven inhalation devices. EDICI. Respir Med 2000;94:496-500.

33. Giraud V, Roche N. Misuse of corticosteroid metered-dose inhaler is associated with decreased asthma stability. Eur Respir J 2002; 19:246-51.

34. Khassawneh BY, Al-Ali MK, Alzoubi KH, Batarseh MZ, Al-Safi SA, Sharara AM, et al. Handling of inhaler devices in actual pulmonary practice: metered-dose inhaler versus dry powder inhalers. Respir Care 2008;53:324-8.

35. Larsen JS, Hahn M, Ekholm B, Wick KA. Evaluation of conventional press-and-breathe metered-dose inhaler technique in 501 patients. J Asthma 1994;31:193-9.

36. George J, Kong DC, Thoman R, Stewart K. Factors associated with medication nonadherence in patients with COPD. Chest 2005; 128:3198-204. 